\title{
IMAGINÁRIO TELÚRICO E IMAGENS DA TRAGÉDIA DE MARIANA ${ }^{1}$
}

\section{Telluric Imaginary and Images on Mariana Tragedy}

\section{Imaginario telúrico e imágenes de la tragedia de Mariana}

Carlos Alberto Orellana, Universidad Federal de Santa Maria (Brasil)

lapisazul2984@yahoo.com.br

Ada Cristina Machado Silveira, Universidad Federal de Santa Maria (Brasil)

adac.machadosilveira@gmail.com

Recebido: abril 15, 2016

Aprovado: Julho 11, 2016

\section{RESUMO}

O texto detém-se na análise de aspectos míticos presentes na cobertura jornalística sobre a destruição ocorrida na noite de 5 de novembro de 2015, no distrito de Bento Rodrigues, na cidade brasileira de Mariana, Estado de Minas Gerais. Dedicamos nossa análise a aspectos visuais da tragédia humana e ambiental. 0 texto possui cinco seções. Inicialmente, abordamos a inscrição dos mitos que facilitam a abordagem de mitemas telúricos no Brasil. A seguir, ocupamo-nos do simbolismo da lama e da poética da terra. A continuação, abordamos as questões da morte e a destruição da vida no Rio Doce. Observamos como o imaginário mítico heroico vem a ser um importante vetor, através do qual o discurso jornalístico propõe suas narrativas, e o imaginário ligado ao universo feminino persiste em noções pejorativas, definidas pelo mitema da lama e suas derivações imagéticas.

Palavras-Chave: imagem, Imaginário, Tragédia, Jornalismo.

1 Trabalho apresentado ao Grupo de Trabalho "Imagem e Imaginários Midiáticos do XXV", no Encontro Anual da Compós, na Universidade Federal de Goiás, Goiânia, de 27 a 30 de maio de 2016. 


\section{ABSTRACT}

The text holds on the analysis of the mythical aspects in the journalistic coverage of the destruction occurred on the night of November 5, 2015 in Bento Rodrigues district in the Brazilian city of Mariana, Minas Gerais. We dedicate our analysis to the visual aspects of human and environmental tragedy. The text contains five sections. Initially, we discuss the application of the myths which facilitate the approach of telluric mythemes in Brazil. Next, we deal with the symbolism of mud and poetic land. On continuation, we address matters of death and the destruction of life in Rio Doce. It can be observed as the imaginary mythical heroic becomes an important vector in which the journalistic discourse proposes their narratives and imaginary related to the feminine universe persist with pejorative notions; that are defined by mytheme mud and its imagery leads.

Keywords: Image, imaginaire, tragedy, journalism.

\section{RESUMEN}

El texto se enfoca en el análisis de los aspectos míticos en la cobertura periodística de la destrucción ocurrida la noche del 5 de noviembre de 2015 en el distrito brasileño de Bento Rodrigues en la ciudad de Mariana, estado de Minas Gerais. Dedicamos este análisis a los aspectos visuales de la tragedia humana y ambiental. El texto contiene cinco secciones. Inicialmente, discutimos la aplicación de los mitos que facilitan el acercamiento a los mitemas telúricos en Brasil. Luego, nos ocupamos del simbolismo del lodo y la poética de la tierra. A continuación, abordamos la cuestión de la muerte y la destrucción de la vida en Rio Doce. Puede observarse cómo el imaginario mítico heroico viene a ser un vector importante, a través del cual el discurso periodístico propone sus narrativas y el imaginario relacionado con el universo femenino persiste en nociones peyorativas, definidas por el mitema del lodo y su imaginería.

Palabras clave: imagen, imaginería, tragedia, periodismo.

\section{Introdução}

O texto detém-se na análise dos aspectos míticos presentes na cobertura jornalística sobre a destruição ocorrida na noite de 5 de novembro de 2015, no distrito de Bento Rodrigues, na cidade de Mariana, Estado de Minas Gerais. Dedicamos nossa análise a aspectos visuais da tragédia humana e ambiental. O texto possui cinco seções. Inicialmente, abordamos a inscrição dos mitos que facilitam a abordagem dos mitemas telúricos no Brasil. A seguir, ocupamo-nos do simbolismo da lama e da poética da terra. A continuação, abordamos as questões da morte e a destruição da vida no Rio Doce.

\section{4}


Antes de prosseguir, buscamos justificar o porquê de analisar imagens veiculadas midiaticamente. Nos termos do consagrado fotógrafo Sebastião Salgado, o evento foi considerado como a maior tragédia ambiental da história do Brasil. Este ponderou que "a catástrofe significa a morte repentina do Vale do Rio Doce que, no entanto, envolve um panorama mais complexo, derivado de intervenções responsáveis pelo esgotamento das matas ciliares pela agricultura intensiva, pela atuação dos poderes públicos de um conjunto de 230 municípios e quatro milhões de habitantes que praticamente não contam com rede de esgotos, jogando no rio todo tipo de poluição, ademais do vale possuir a maior concentração de minerais do mundo" (Época Online, 2015.).

Criador do "Instituto Terra", situado em propriedade de sua doação, e conveniado à empresa Vale do Rio Doce, com o projeto "Olhos d'água" dentre outras, caberia a Sebastião Salgado uma declaração no sentido de promover esforços para a recuperação dos danos(Instituto Terra, 2016). Mas teria o prestígio do foto jornalista algum poder de amenizar a tragédia? Ademais, como a cobertura da mídia foi lenta e restrita, especialmente tendo em consideração o clamor em torno dela, Salgado foi cobrado a respeito da oportunidade de seu engajamento numa causa social, num território que lhe é familiar. E a notícia que despontou como presente natalino correspondeu ao anônimo fotógrafo profissional Elcio Pereira Rocha. Ele doaria fotos pessoais e familiares das vítimas que possuía em seus arquivos (Portal G1, 2015).

John Mraz (1998) entende que o fotojornalismo de Salgado deve ser tomado como fine art, ao inclinar-se mais para o polo expressivo do que ao informativo, ocupado antes com a simbolização do que com o referente da fotografia. São fotos que despertam para a dignidade do humano, avassalado por distintas condições socioeconômicas, abrindo uma discussão sobre a possibilidade de uma estética da miséria e suas implicações éticas, conforme apontou Carla V. Albornoz (2005).Assim, a Salgado é atribuída uma estética fotográfica pós-moderna, quando este busca mostrar a "crise do real", reiterada quando afirma: "I belive that there is a Latina American way of seeing the wolrd. It's something you can't teach, it's part of you" (MRAZ Online, 1998.).

No livro de fotografias "Outra América", Salgado teria dado um passo adiante, ligando a alienação à vida tradicional: tristeza, miséria, morte e enigma são onipresentes no conteúdo de suas imagens (MRAZ Online, 1998.). Já para a promoção de seu mais recente livro, conforme se apresenta no site da editora alemã Taschen, o fotógrafo desponta por sua reconhecida comiseração frente à condição socioeconômica avassaladora de parte da humanidade. Em "Gênesis", Salgado buscou aproximar-se da "natureza e da ecologia", ao entender que quase metade do território do planeta encontra-se como "no dia da criação" (Istoé Online, 2015.).

É apontando a profunda ironia que colhe o consagrado fotógrafo brasileiro que começamos nossa análise sobre o caráter mítico das imagens sobre a tragédia de Mariana.

\section{Mito e imaginário sobre a terra no Brasil}

O presente texto foi escrito por intenção de duas vontades e aquatro mãos. Detidos em aspectos inconscientes, míticos e simbólicos que impregnam a narratividade midiática, os analisamos quando especialmente alocados na aparente normalidade do acontecer, agenciada pela objetividade jornalística.

Para desenvolvimento de nossa proposta de análise, estudamos a cobertura jornalística da destruição do tecido urbano do distrito de Bento Rodrigues, ocorrida na noite de 5 de novembro de 2015, na cidade de Mariana, 


\section{ESTUDIOS}

Estado de Minas Gerais, em razão do rompimento de uma barragem de rejeitos minerais, apontando aspectos visuais da tragédia humana e ambiental.

Inicialmente destacamos que há uma tradição dedicada a inscrever os mitos nacionais brasileiros como derivados de mitemas telúricos, tais como: "o gigante adormecido" "o Brasil profundo", "nesta terra, em se plantando, tudo dá", "terra abençoada por deus", e outras derivações de imagens obsessivas sobre um esquema de repouso, acolhimento e reprodução. $O$ texto fundador da Carta de Pero Vaz de Caminha inaugurou a existência discursiva do Brasil a partir da visão da Enseada de Santa Cruz, em termos de paraíso-purgatório, em que são evidenciadas a ingenuidade e a inocência dos gentios (Castro, 1985).

E se acreditamos que os mitos são fontes fundadoras dos discursos sociais, no qual o real não é apenas estudado, mas sentido e vivenciado, os mitos não são resíduos de uma longa trajetória antropológica, mas sim vetor de inserção do homem no campo simbólico e na experiência social. Assim, através do mito como uma "imagem narradora", que compõe um quadro de compreensão do real, é que se pode relacioná-lo à experiência cotidiana.

Tomamos em consideração um vídeo amador inserido em reportagem realizada pelo "Jornal Nacional", da Rede Globo de TV, exibida em 7 de novembro de 2015 (figura 1). Analisamos como suas imagens possibilitam que o discurso jornalístico convoque elementos míticos para a formação de um quadro sobre a tragédia do rompimento da barragem de Fundão, repleta de rejeitos da empresa mineradora transnacional Samarco:

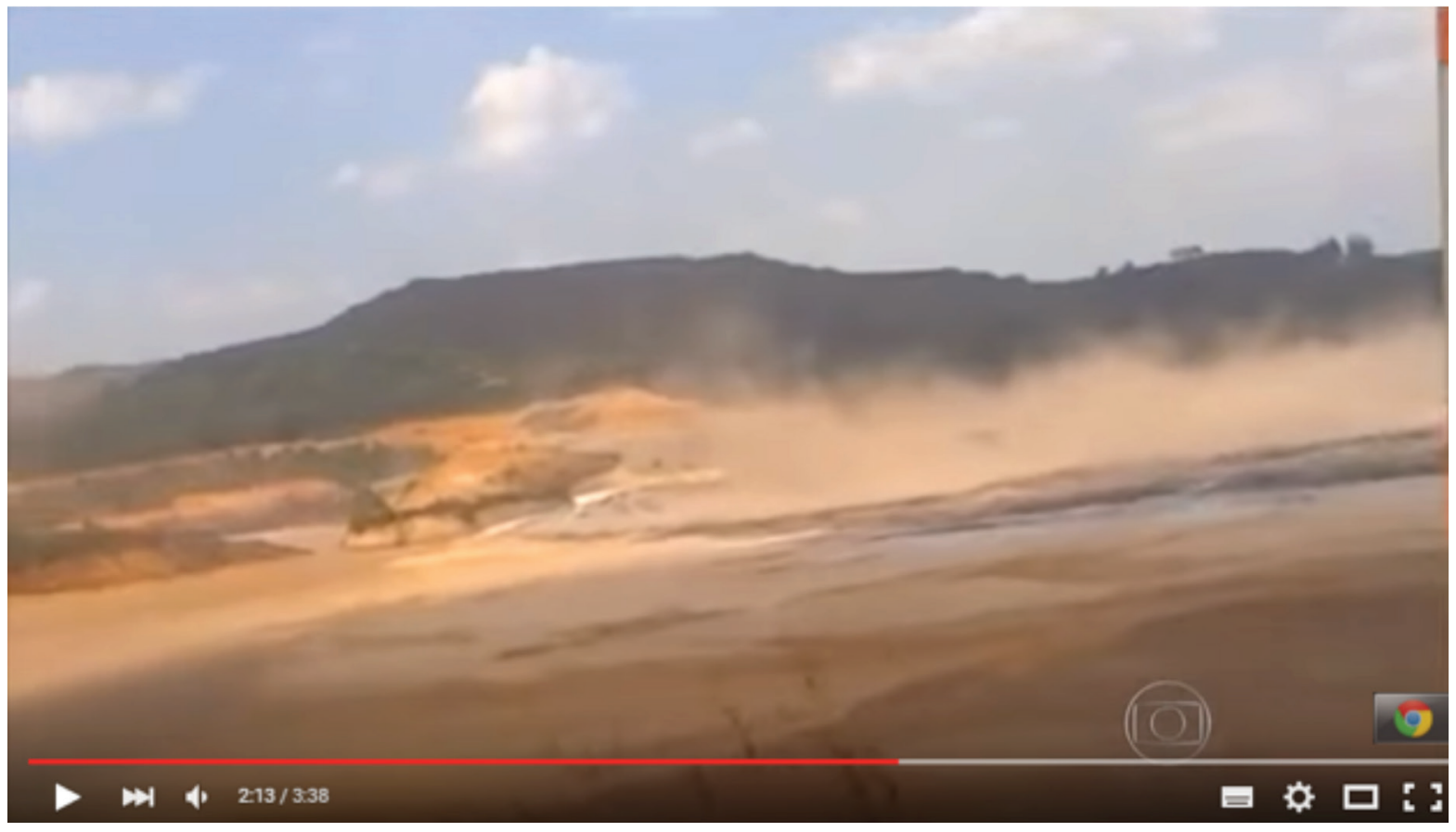

Figura 1 - Imagem do vídeo de destruição da barragem

Fonte: https://www.youtube.com/watch?v=YCErCk9byt8 
$\mathrm{Na}$ análise que realizamos, perfilam-se duas hermenêuticas acerca da narrativa sobre o Profeta Jonas, com vistas a produzir uma aproximação com a significação plasmada na narratividade midiática, centrados na cobertura jornalística do acontecimento.

Como observa Bachelard (1990), o mito de Jonas exerce um fascínio sobre o aspecto do devaneio de intimidade, da intimidade da gruta. Podemos observar essa intimidade que o elemento terra sugere, pois há no discurso midiático um reiteramento dos aspectos bucólicos da vila de Bento Rodrigues, da cena pacata, de uma localidade que presenciou uma tragédia. Isso pode ser exemplificado em relação aos termos distrito e vilarejo, que identificam aquele espaço na região central de Minas como determinado por uma relação social coesa entre seus habitantes, como familiares ou amigos de seiscentos moradores. Uma hipótese que levantamos é a de que essa mesma característica bucólica fez com que a grande mídia apostasse na possibilidade de negligenciar os efeitos do evento. Não se tratou tão somente de um vilarejo encoberto, de vidas ceifadas, mas ainda do deslocamento da lama em direção ao mar na região turística de Abrolhos, ademais de seu impacto sobre o fornecimento de água no transcurso por cidades dos Estados de Minas Gerais e do Espírito Santo.

O vetor de deglutição da lama foi o principal das narrativas midiáticas, em particular, o aspecto de devoramento, da morbidez deglutiva, das imagens cósmicas da terra devoradora, aliada ao impulso da fluidez aquática capaz de submergir vilarejos inteiros, como foi o caso de Bento Ribeiro.

Como Bachelard (1990) destaca com os mitos dos monstros marinhos que devoram barcos ou de peixes grandes engolindo os peixes menores, a fluidez e viscosidade da lama está presente no discurso midiático quando são destacados os termos como: rio de lama, correnteza de lama. Sua figuração aparece nas imagens trepidantes da lama escoando quando houve o rompimento da barragem, e que foram produzidas por funcionários da empresa mineradora Samarco.

Destacamos que em o mito de Jonas, uma matéria capaz de revelar as condições pelas quais o discurso televisivo produziu sobre o acontecimento. As imagens de Jonas no ventre de uma baleia são elementos que nos auxiliam a compreender o desastre de Mariana, pois evocam imagens de acomodação, de nadificação digestiva, de acolhimento. Entretanto, a lama, principal mitema presente no discurso sobre a tragédia de Mariana, se articula com uma nadificação digestiva de caráter negativo, no qual a lama envolve o vilarejo, as ruas, os moradores, como a fome de um glutão. A proteção do ventre que a terra exerce sobre os esquemas simbólicos dá lugar à voracidade digestiva, numa síntese entre imagens de integração e destruição. De tal modo, os moradores desaparecidos não são nomeados ou mesmo apresentadas suas imagens, como se a lama tivesse engolido até sua identidade e os reintegrasse numa só entidade coletiva: os moradores, vítimas ou desaparecidos de Bento Rodrigues, em Mariana.

Consideramos, assim, que a lama faz-se num mitema importante para compreensão do evento; a lama alia as propriedades da terra e da água, um elemento intermediário que apresenta a fluidez e instabilidade da água com a força e estabilidade da terra. A lama torna-se uma intersecção entre as propriedades da terra (dureza, aspereza, densidade, força telúrica e solidez), com as propriedades de água (transbordamento, corredeira, deslize, evasão, fluidez e escoamento). Tais propriedades, ao interseccionar-se pelo rompimento da represa, criam o efeito misto de fluidez sólida, rio de material sedimentar que devasta o que encontra pela frente, tanto por seu aspecto de corrimento quanto pelo de sua solidez.

Em Bachelard (1990), a terra é vivida como um esquema biomorfológico do repouso. Com o advento da catástrofe, a lama torna-se o polo inverso do esquema de repouso, e ganha as características de água. A lama "invade", 
"destroi", "corre", "desliza" como a água, e inverte-se em direção ao polo negativo, visto que ela corporifica a terra, ganha volume e densidade que a água não apresenta.

Analisando por outro aspecto, o devaneio da terra exerce duas funções: uma de ventre sexual e outra de ventre digestivo. Quanto ao aspecto digestivo, podemos considerar a avidez do engolimento, que pode ser verificada nas imagens de soterramento, de invasão, cobertura da terra onde antes havia casas, ruas e escolas. 0 autor aponta que uma das imagens obsessivas desse aspecto digestivo da terra é da vítima engolida, da ofensividade e violência das imagens derivadas desse esquema de engolimento de um vilarejo. Verificamos nas imagens produzidas que também é possível reconhecer o esquema do engolimento nos corpos dos desaparecidos. Trata-se, portanto, não apenas do desaparecimento da vida biológica de seres vegetais e animais, dentre os quais as vítimas humanas, como também de seus corpos.

Verificamos o mitema presente nos discursos jornalísticos, na medida em que não conseguem definir a lama, sendo usados os termos: resíduos de minério, resíduos de ferro, lama e água. A água que ganha funções de limpeza e higiene nos esquemas simbólicos ocidentais, é invertida quando ela se mistura à terra, a lama torna-se uma metáfora da sujeira, de iniquidade, de toxidade.

\section{simbolismo da lama e a poética da terra invertida}

A lama torna-se símbolo de escoamento e erosão de energias simbólicas, pois a terra na abordagem de Bachelard (1990) libera aspectos de impulso sexual e da vida, a lama funciona a partir de esquemas duplo de pulsão sexual e de acolhimento, que é traído quando a terra assume aspectos aquáticos. A água assume, em contextos simbólicos, a propriedade das profundezas e da morte, e acaba sendo ressignificada pelo elemento terra, que possui o sentido de leito da vida e da reprodução. Assim, a lama é uma terra com as propriedades negativas da água, uma terra que não produz, mas que destrói, invade e torna o ambiente inóspito e inabitável.

Além disso, os termos barragem e represa, usados frequentemente no discurso jornalístico, ocorrem num contexto simbólico, que se confunde com a ideia de contenção da água, o que acaba por mesclar a duplicidade dos elementos.

Dentre as propriedades da lama, convém apontar que, ao mesmo tempo em que destrói a capa superficial do solo, ela seca, enrijece, impregna e cria uma crosta que solidifica o desastre. Figura-se uma espécie de aprisionamento por obra da atemporalidade. Assim, percebemos nas imagens do desastre de Mariana como tem sido enquadrada no campo midiático, uma poética da terra invertida, isto é, ao invés de servir como espaço de proteção e cultivo, a terra torna-se vilã, inimiga que esconde seus mortos, que soterra, tal qual a erupção vulcânica do Vesúvio, que converteu uma cidade em mausoléu.

Nas imagens aéreas do distrito de Bento Rodrigues, torna-se um elemento imagético importante de análise, um carro sobre o teto de uma casa destruída, isto é, a partir do momento em que os elementos estão embaralhados e não mais cumprem suas funções e espaços, é que a tragédia pode ser compreendida. Um carro encontrado sobre um telhado é a marca da violência, da força da lama em direção ao vilarejo (figura 2). 0 carro é signo desse embaralhamento de sentidos entre as propriedades da água e da terra. Ocarro foi erguido pela solidez e volume da terra e a fluidez das águas. 


\section{ESTUDIOS}

Anuario electrónico de estudios en Comunicación Social

ISSN: 1856-9536

Doi: http://dx.doi.org/10.12804/revistas.urosario.edu.co/disertaciones/a.4789

Volumen 10, Número 2 / Julio-diciembre 2017

Versión PDF para imprimir desde

http://revistas.urosario.edu.co/index.php/disertaciones

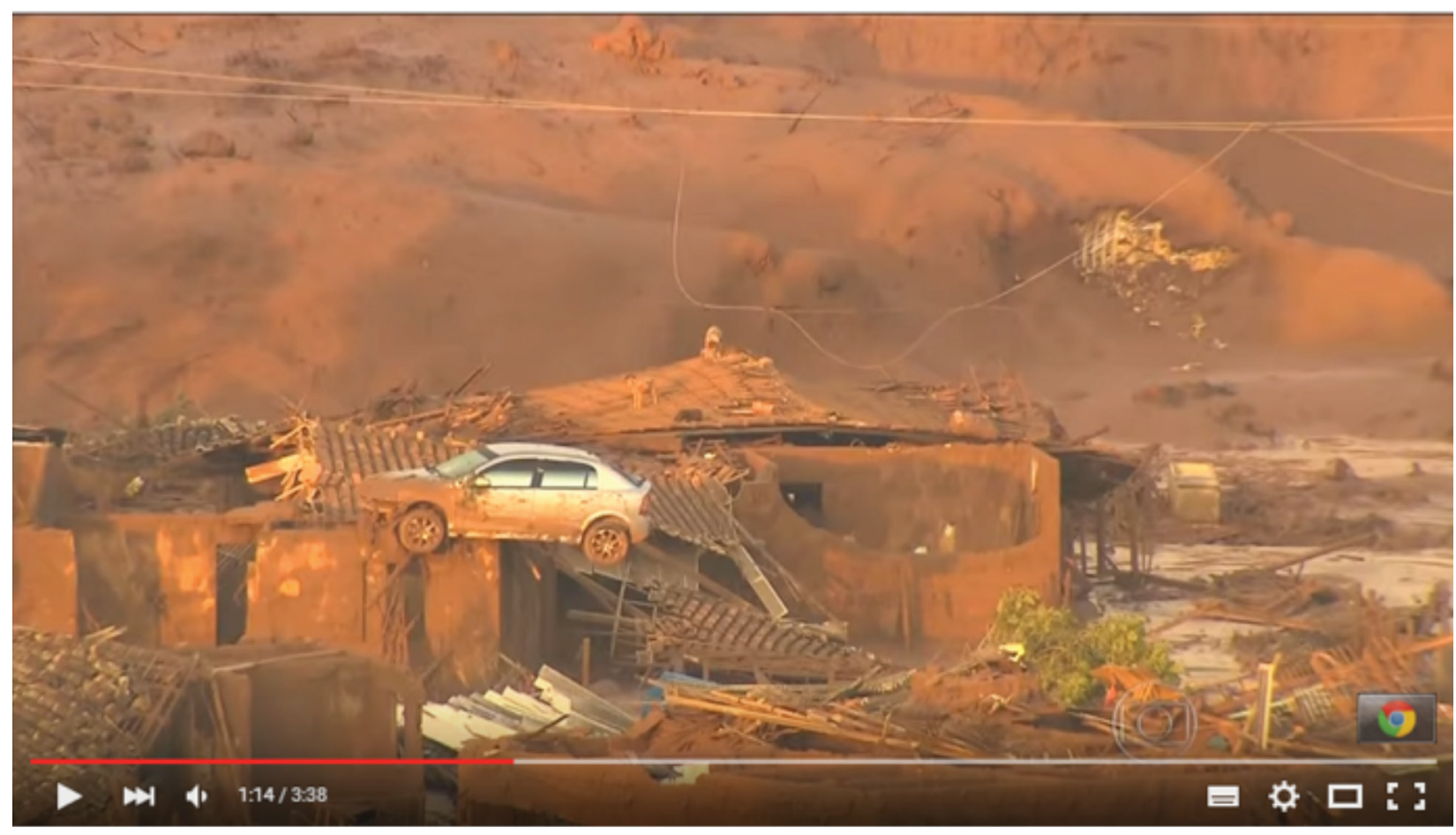

Figura 2 - Imagem da destruição com um carro sobre um telhado

Fonte: https://www.youtube.com/watch?v=YCErCk9byt8

As derivações que a lama de rejeitos minerais ganha num contexto simbólico como portadora de um enigma como enfrentar algo que não é exclusivamente terra ou água. O processo dialético instaura-se, o que agrava ainda mais o percurso do discurso midiático, a partir de que as mídias tradicionais se articulam por esquemas tipificadores e redutores, ou seja, como avaliar um fenômeno social complexo que se instaura num contexto ambiental determinado, aliado aos mitemas telúricos que fundam nossa identidade nacional.

Como descreve Gaston Bachelard (1990, p.115) em "A terra e os devaneios do repouso": "O complexo de Jonas irá marcar todas as figuras do refúgio com este signo primitivo de bem-estar suave, cálido, jamais atacado. E um verdadeiro absoluto de intimidade, um absoluto do inconsciente feliz". Assim, o desastre foi dificilmente assimilado pelas mídias tradicionais do país devido a esse fator que a terra evoca, da calidez e de proteção, a lama inverteu essas representações de acolhimento e ressignificou, nos termos de afogamento aquático e soterramento. Analisamos que a lama surge em raras ocasiões nos discursos midiáticos, surgindo como elemento de erosão e desmoronamento de encostas de ocupação irregular urbana de regiões periféricas metropolitanas. A lama como símbolo de pobreza e de favelas brasileiras entra no debate nacional como elemento do maior desastre ambiental, isto é, a lama deixa seu contexto delimitado de pobreza para a discussão ambiental e econômica de atividades como mineração de ferro, uma das principais commodities brasileiras. 
Entretanto, percebemos que essa duplicidade da lama pelo seu caráter aquático, mineral e terreno, assume suas contradições quando a lama nos vilarejos deixa de ser o foco de atenção, para ser a preocupação no abastecimento de água de cidades de Minas Gerais e Espírito Santo até sua chegada ao mar. A lama, por suas propriedades como densidade, sujeira e turbidez, nega as qualidades da água potável e faz com que discursos midiáticos anunciem a morte do Rio Doce e sua bacia hidrográfica, apresentem peixes mortos ao longo de seu caudal e revelem o contraste cromático entre as águas contaminadas pela lama, no encontro com as águas do oceano Atlântico, criando o efeito bicolor que sugere o logotipo da empresa Vale do Rio Doce (figura 3):

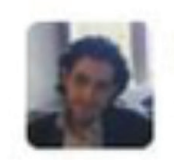

\section{The Flecha i}

@arrowp

\section{bela publicidade, só custou o meio ambiente}

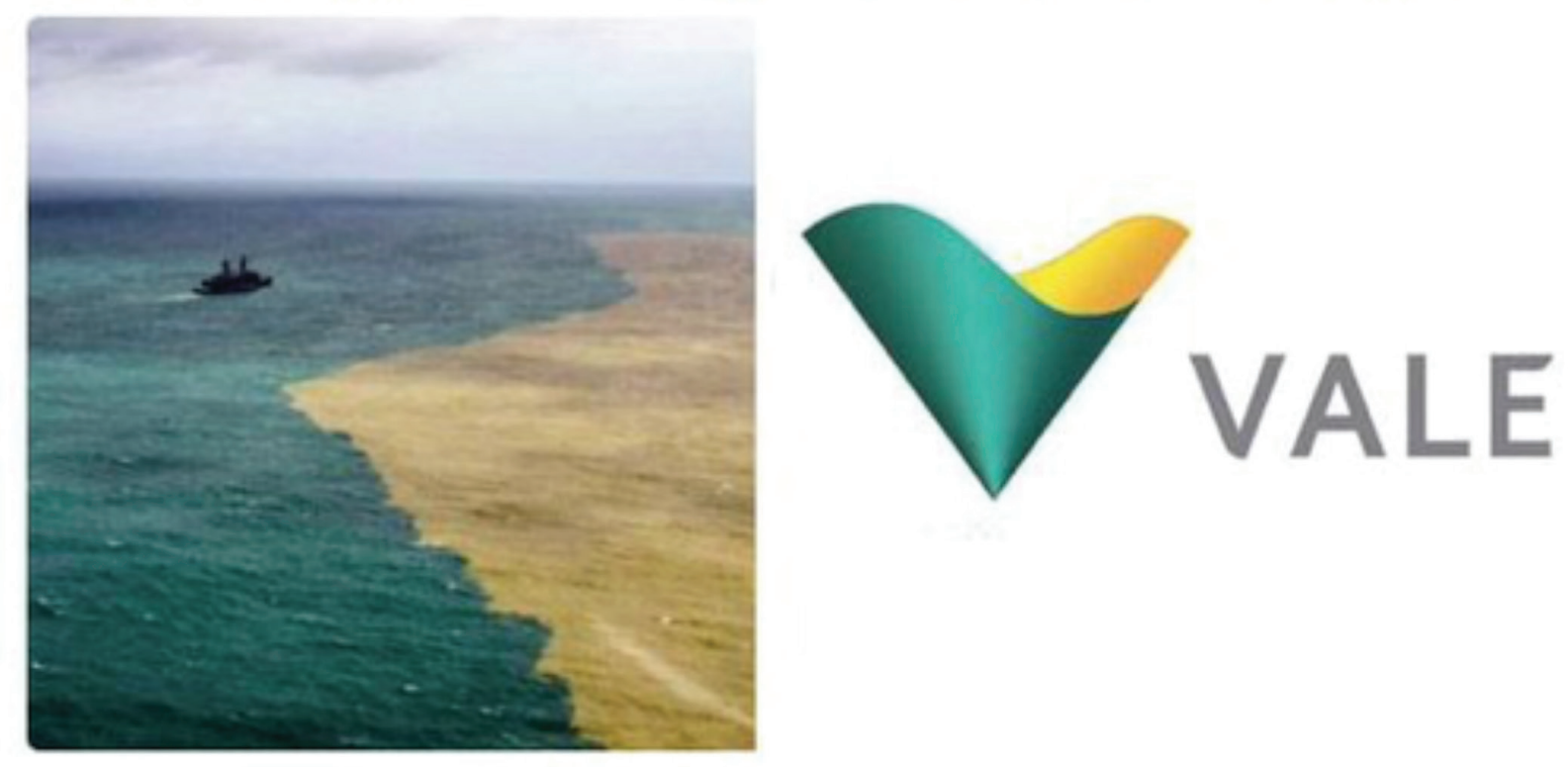

Figura 3 - Imagem do mar e do logotipo da empresa Vale do Rio Doce

Fonte:- http://g1.globo.com/economia/midia-e-marketing/noticia/2015/11/internautas-associam-

\section{imagem-de-lama-no-mar-logo-da-vale.html}

Bachelard, apoiado na obra de Carl Gustav Jung, compreende que o mito de Jonas configura-se como uma narrativa alquímica, expressa numa ordem decrescente entre a matéria uterina e a água primitiva. Uma escala de valor para a qual o princípio de vida desce em direção ao mercúrio, considerado como princípio feminino e de escoamento. 
Esses princípios alquímicos são reativados mesmo que inconscientemente no discurso jornalístico na medida em que os resíduos de ferro presentes no rejeito resultante da exploração mineradora são ativados como elemento predominante na lama que vazou da barragem. $\mathrm{O}$ ferro, nos princípios alquímicos, liga-se ao planeta Marte e às qualidades do seu regente como força, resistência, representado pelo escudo de Marte $\Downarrow$, símbolo identificado como vetor masculino de dominação. A fúria do elemento ferro, por identificação mitológica do deus Marte, é ressignificado pelos usos midiáticos de expressões como "enxurrada", "força" e "violência" da lama.

O conjunto de vetores masculinos que são negociados conta, assim com o princípio alquímico do ferro com um outro, passivo, que é o do mercúrio. Ademais da passividade, mercúrio é úmido e promove um retorno ao estado primordial, sendo representado pelo caduceu, um objeto de insígnia dos arautos. O mercúrio, ainda de acordo com princípios alquímicos, seria um elemento de transição entre estados físicos sólido e líquido, entre vida e morte, popularizado no termômetro que por ele indicializa a temperatura corporal. Já no imaginário do mundo das notícias, é um elemento metálico que possui em condições normais e se apresenta sob a forma líquida. Na mitologia grega, sua denominação é de Hermes, o mensageiro, sendo comum a denominação de mercúrio a muitos jornais, como o grupo de diários do Chile, onde se destaca o quase bicentenário "El Mercurio de Valparaíso", bem como um extinto diário da Espanha e circulantes no presente em países diversos, como o Equador e México, dentre outros.

Neste sentido, o mito de Jonas investido por uma lógica alquímica, sugere pistas para a compreensão de elementos míticos presentes nos discursos midiáticos. 0 elemento ferro simbolizaria o vetor masculino. Seu princípio vinculado à lama detentora de qualidades transicionais do mercúrio afiançam forças virtualmente produtoras de imagens obsessivas sobre a tragédia de Mariana.

O mito de Jonas convoca ainda um aspecto sexual, de novo nascimento, de abandono do princípio de proteção uterina. No entanto, no evento de Mariana, esse aspecto é convocado em seu aspecto da morbidez. A lama não apenas engole, mas também aniquila. Recordando Bachelard, o herói no mito de Jonas é engolido e preservado no interior da baleia, de onde pode recorrer a estratégias de fuga do interior do animal. Um processo de gestação que se afirma no engolimento e proteção uterina.

0 aspecto do nascimento e proteção uterina é convocado quando são mostradas as imagens do "ginásio de esportes foi transformado em abrigo", ou em reportagens sequentes que questionam o "novo lar" ou abrigos provisórios das pessoas prejudicadas pela tragédia na cidade. 


\section{ESTUDIOS}

Anuario electrónico de estudios en Comunicación Social

ISSN: $1856-9536$

Doi: http://dx.doi.org/10.12804/revistas.urosario.edu.co/disertaciones/a.4789

Volumen 10, Nümero 2 / Julio-diciembre 2017

Versión PDF para imprimir desde

http://revistas.urosario.edu.co/index.php/disertaciones

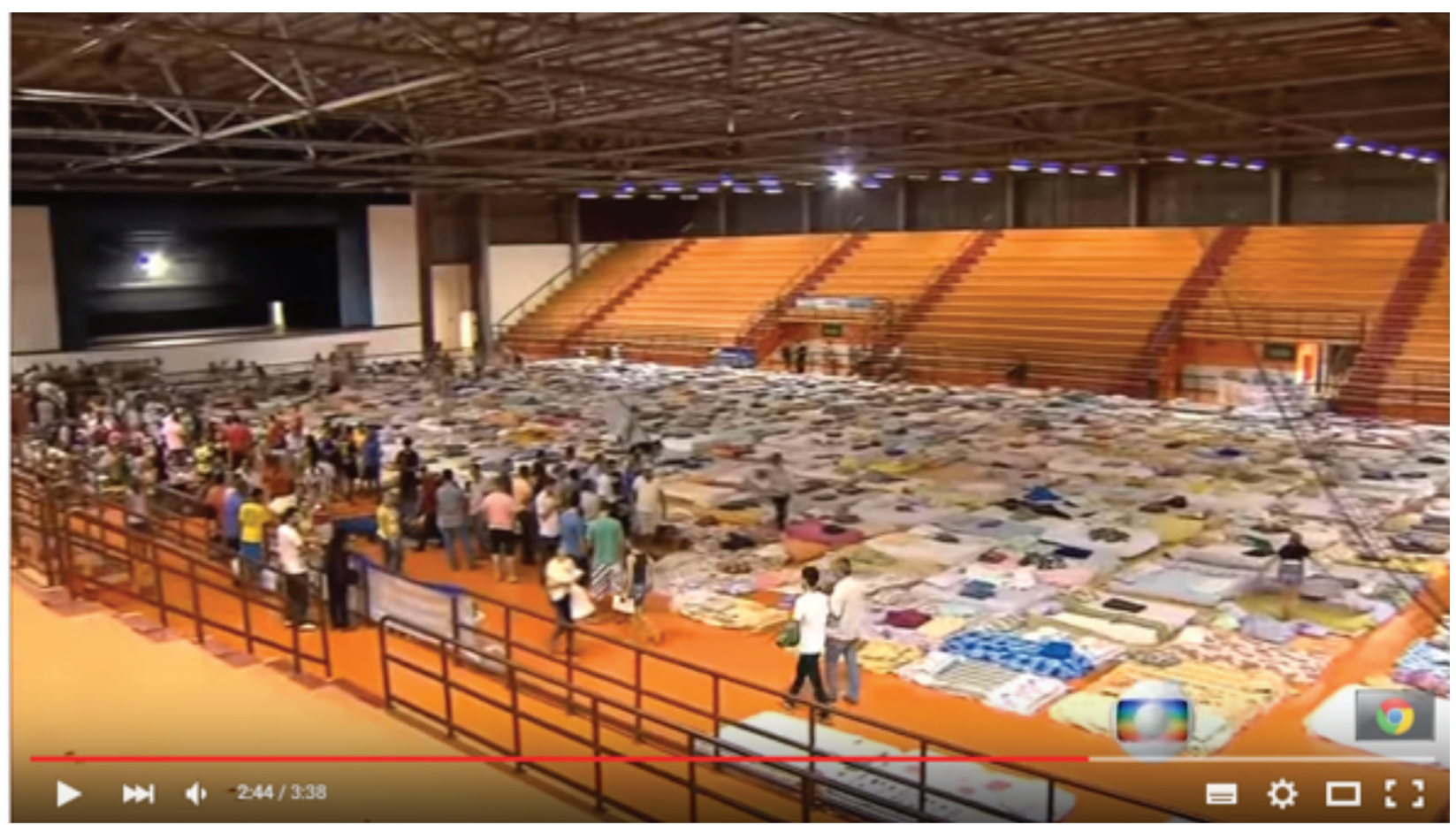

Figura 4 -Imagem do ginásio de esportes

Fonte: https://www.youtube.com/watch?v=YCErCk9byt8

\section{A morte e a destruição da vida no Rio Doce}

O aspecto da sujeira é convocado como o oposto à pureza das águas ou como descrito em reportagens posteriores às águas barrentas. A lama torna a água imprópria para o consumo, que por sua vez "mata o Rio Doce". A abrupta destruição da vida vegetal e animal na bacia hidrográfica do Rio Doce foi tema central de outras reportagens que se seguiram à devastação do distrito de Bento Rodrigues. A morte do rio é anunciada pelas propriedades de turbidez e coloração da água em contraposição à limpidez e transparência esperadas numa correnteza fluida. Destacamos que no imaginário da vida ainda alinham-se ao universo mítico heroico de pureza, limpidez e clareza, enquanto o imaginário da morte relaciona-se com o universo mítico místico das profundezas, da escuridão e da turbidez.

Outro aspecto a ser analisado é a qualidade de sujeira que a lama sugere, isto é, as impurezas da água e da terra misturados que acabam por criar o sentido de contaminação, próprio dos rejeitos de exploração mineral e que impregnam o discurso jornalístico daquilo que a posse da terra nos tem assegurado: "solidez do mental, das certezas dos valores seguros" (Dravet, s.d.) que, como se vê, não mais nos asseguram nada, pois até os minérios que nos enriquecem passaram a nos intoxicar. 
Como destaca Bachelard (1990), a terra apresenta um caráter onírico de ser oco, da constante do devaneio da intimidade, da acomodação e do repouso. Assim, a lama quebra com esse aspecto da acomodação e do repouso, restaurando um devaneio do desequilíbrio, da inconstância e do ritmo. Podemos observar essa quebra de sentido pela própria tradição histórica da região afetada, que é chamada das Minas Gerais, decorrente tanto de seu aspecto econômico quanto do aspecto simbólico de um Brasil profundo, tradicional, antigo, que por sua importância definiu os rumos políticos e sociais do país nos últimos três séculos. Esse aspecto do Brasil profundo versus o Brasil litorâneo será usado nas matérias jornalísticas subsequentes à analisada quando é dada ênfase na poluição do material nas praias do Espírito Santo, e no encontro das águas do mar com a água do rio contaminado pela lama. 0 equilíbrio de valores jornalísticos é tênue neste aspecto, pois se cria o efeito de que as vidas perdidas no distrito de Bento Rodrigues talvez não fossem tão importantes quanto o impacto ambiental sobre o litoral. Um Brasil profundo que vem interferir na lógica do Brasil litorâneo, quando os dois Brasis são categorizados e interpretados em lógicas distintas pelos discursos midiáticos.

A cobertura jornalística, ademais, ocorre num momento particular, pelo qual é possível derivar-se para um patamar de sentido em que a sujidade não apenas é atributo do evento trágico ao redirecionar o interesse discursivo advindo do tema do desastre ambiental para a esfera das questões políticas. A oportunidade da crise política vivenciada no ano de 2015 articula as denúncias de corrupção econômica como foco disputado, no momento da tragédia de Mariana, com a cobertura jornalística da denominada "Operação Lava-jato" determinada pelo poder Judiciário e seus desdobramentos.

\section{Conclusão}

Ao pontificar que o imaginário mítico heroico vem a ser um importante vetor pelo qual o discurso jornalístico propõe suas narrativas, observamos que nos imaginários ligados ao universo feminino, persistem noções pejorativas que são definidas pelo mitema da lama e de suas derivações imagéticas. Recordamos o enfoque desenvolvido por Florence Dravet (s.d., Online), quando articula a figura do feminino como um dos monstros catastróficos e aponta na tapeçaria medieval do Apocalipse a imagem da prostituta sobre as águas. Dravet encaminha uma digressão para Oxum, deusa das águas doces, e filha de lemanjá.

A análise aqui esboçada permite compreendemos que a lama, no sentido mítico, sintetiza os valores pelos quais o discurso jornalístico compreende a sociedade e sua função, isto é, uma moção social ligada ao desenvolvimento retilíneo e crescente proveniente da tradição iluminista, sua função emancipadora e esclarecedora, tomando-se o clarear como antípoda da turbidez da lama sobre os agentes sociais.

A lama como mitema desenvolve uma intensa relação sobre o imaginário nacional brasileiro. Em conformidade ao esquema de análise aqui proposto a partir da tragédia de Mariana, postulamos uma hipótese sobre as imagens midiáticas do Brasil. Entendemos ser pertinente apontar que, especialmente o discurso jornalístico nacional sobre o Brasil, sustenta uma compreensão estigmatizada e atrelada ao mundo colonial-escravocrata, quanto ao controle da terra e suas riquezas, concebendo-se a partir daí suas derivações míticas. Apesar de se constituir como nação poderosa, Estado territorialmente grande, com um solo rico em minérios e de grande produção agrícola, os vetores ligados à terra são vistos nas imagens de brasileiros sobre o Brasil com passividade, traços de subdesenvolvimento e obscuridade. Sua figuração carece de elementos enriquecedores para uma tradição mito- 


\section{DISERTACIONES}

ESTUDIOS

Anuario electrónico de estudios en Comunicación Social

ISSN: 1856-9536

Doi: http://dx.doi.org/10.12804/revistas.urosario.edu.co/disertaciones/a.4789

Volumen 10, Número 2 / Julio-diciembre 2017

Versión PDF para imprimir desde

http://revistas.urosario.edu.co/index.php/disertaciones

lógica, característica observável quando comparados à tradição mitológica heroica ascencional e aérea dos países da antiguidade que constituem o imaginário ocidental.

\section{Referências}

1. Albornoz, C.V. (2005). Sebastião Salgado: o problema da ética e da estética na Fotografia Humanista Contemporânea, Rio de Janeiro. Recuperado de http://www.e-publicacoes.uerj.br/index.php/contemporanea/ article/view/17069

2. Bachelard, G.(1990). A terra e os devaneios do repouso. São Paulo: Martins Fontes.

3. Castro, S.(1985). O descobrimento do Brasil: A Carta de Pero Vaz de Caminha. Porto Alegre: L\&PM.

4. Dravet, F. (2016, 30 de janeiro).A figura do feminino no Apocalipse de Angers. Recuperado de https://www. academia.edu/10839843/A_figura_do_feminino_na_tape\%C3\%A7aria_do_Apocalipse_de_Angers

5. Época. (2016, 7 de fevereiro). Sebastião Salgado: essas empresas primam pela preocupação ecológica.24/11/2015. Recuperado de http://epoca.globo.com/tempo/noticia/2015/11/sebastiao-salgado-essas-empresas-primam-pela-preocupacao-ecologica.html

6. Instituto Terra. (2016, 4 de fevereiro). Comunicado sobre o Rio Doce. 13/11/2015. Recuperado de http:// www.institutoterra.org/pt_br/ShowNot.php?adfo3;76ad;/kjioerg=MjQx\&er67sd23fda=TVE9PQ==\#. VrOfmWQrJJW

7. Instituto Terra. (2016, 4 de fevereiro).Demonstrações financeiras dos exercícios findos em 31 de dezembro de 2013 e 2012.Recuperado de http://www.institutoterra.org/pt_br/searchContas.php\#.VrOhOGQrJJU

8. Istoé. (2016, 20 de janeiro). Caminhos para o fim da fotografia. Ed. n. 2367. Recuperado de http://www. istoe.com.br/assuntos/entrevista/detalhe/413300_CAMINHAMOS+PARA+O+FIM+DA+FOTOGRAFIA+

9. Mraz, J. (1998). Sebastião Salgado's Latin America. Estudios Interdisciplinarios de América Latina y el Caribe, Tel Aviv. 9 (1). Retrieved from http://eial.tau.ac.il/index.php/eial/article/view/1092/1124

10. Portal G1. (2016, 4 de fevereiro).Fotógrafo resgata fotos e presenteia moradores. Recuperado de http:// g1.globo.com/jornal-nacional/noticia/2015/12/fotografo-resgata-fotos-e-presenteia-moradores-de-mariana-mg.html

11. Taschen. (2016, 4 de fevereiro). Tierra eterna. Recuperado de http://www.taschen.com/pages/es/catalogue/photography/all/05767/facts.sebastio_salgado_genesis.htm 